\title{
Anti-inflammatory Effects of Aster yomena Extracts by the Suppression of Inducible Nitric Oxide Synthase Expression
}

\author{
Ah-Yeon Kim ${ }^{1, \$}$, Hyeon-Myeong Shin ${ }^{1, \$}$, Ji-Soo Kim ${ }^{2, \S}$, Hyun-Jin Shim ${ }^{1}$, \\ Kung-Woo Nam ${ }^{3}$, Kyung-A Hwang ${ }^{4}$ and Hyung-Sun Youn ${ }^{1,2, \dagger}$ \\ ${ }^{I}$ Department of Biomedical Laboratory Science, College of Medical Sciences, \\ Soonchunhyang University, Chungnam, Asan 31538, Korea \\ ${ }^{2}$ Departments of Medical Science, College of Medical Sciences, SoonChunHyang University, \\ Chungnam, Asan 31538, Korea \\ ${ }^{3}$ Department of Life Science and Biotechnology, College of Natural Science, \\ Soonchunhyang University, Asan 31538, Korea \\ ${ }^{4}$ Department of Agrofood Resources, National Academy of Agricultural Science, RDA, Wanju 55365, Korea
}

\begin{abstract}
Inflammation is a pathophysiological process that is known to be involved in numerous diseases. Microbial infection or tissue injury activates inflammatory responses, resulting in the induction of proinflammatory proteins including inducible nitric oxide synthase (iNOS). Aster yomena is used in traditional Korean remedies. Here, we investigated the effects of ethanol extracts of Aster yomena (EAY) on the expression of iNOS induced by ovalbumin (OVA), one of the major egg allergens, or lipopolysaccharide (LPS), a Toll-like receptor 4 agonist. EAY inhibited OVA- or LPS-induced NF-kB activation. EAY also suppressed OVA- or LPS-induced iNOS expression and nitrite production. These results suggest that EAY has the specific mechanism for anti-inflammatory responses and the potential to be developed as a potent anti-inflammatory and anti-allergic drug.
\end{abstract}

Key Words: Aster yomena; Inducible nitric oxide synthase; Ovalbumin; LPS; Inflammation

\section{서 론}

선천성 면역 반응은 거의 모든 생물체에 존재하는 숙 주의 방어 체계로서, 병원균에 대항하기 위한 숙주의 최 초 방어 체계라 할 수 있다(Takeda and Akira, 2005). Tolllike receptor (TLR)가 선천성 면역 반응을 위해서 중요한 역할을 한다고 알려져 있으며, 현재까지 적어도 13 개의 TLRs가 포유동물 세포 안에서 발견되었다(Kawai and Akira,
2007). TLRs는 myeloid differential factor 88 (MyD88)과 Toll/ IL-1R domain-containing adaptor inducing IFN- $\beta$ (TRIF)를 통 한 두 개의 신호전달 경로를 가지고 있으며, 전사 요소 nuclear factor $\kappa B$ (NF- $\kappa B$ ) 또는 interferon (IFN) regulatory factor 3 (IRF3) 활성화를 유도한다(Kawai and Akira, 2007). 활성화된 전사 요소는 cytokine, cyclooxygenase-2 (COX-2), inducible nitric oxide synthase (iNOS) 등과 같은 염증을 유 발하는 유전자들을 유도하여 여러 질병을 유발하게 된다 (Takeda and Akira, 2005).

\footnotetext{
* Received: May 12, 2017 / Revised: June 28, 2017 / Accepted: June 28, 2017

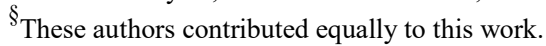

${ }^{\dagger}$ Corresponding author Hyung-Sun Youn. Department of Biomedical Laboratory, College of Medical Sciences Science, Soonchunhyang University, 646 Eupnae-Ri, Shinchang-Myun, Asan-Si, Chungnam 336-745, Korea.

Tel: +82-41-530-3086, Fax:+82-41-530-3085, e-mail: hyoun@sch.ac.kr

(C) The Korean Society for Biomedical Laboratory Sciences. All rights reserved.

(c) This is an Open Access article distributed under the terms of the Creative Commons Attribution Non-Commercial License (http://creativecommons.org/licenses/by-nc/3.0/) which permits unrestricted non-commercial use, distribution, and reproduction in any medium, provided the original work is properly cited.
} 
음식 알러지(food allergies)는 만성적인 장애를 일으킬 수 있는 음식 단백질에 대한 면역 거부 반응으로 우유, 계란, 대두, 땅콩, 생선 등이 중요한 식품 알러젠들로 알려 져 있다(Wang and Sampson, 2009). 이러한 알러젠들 중 계 란은 아이들에게 두 번째로 흔한 음식 알러젠으로 알려져 있다(Eggesbo et al., 2001). 계란 알러젠으로는 lysozyme, ovomucin, ovomucoid, ovalbumin (OVA) 등이 있으며, 이 중 에서 $\mathrm{OVA}$ 은 계란 흰자 단백질 중 약 $54 \%$ 로 가장 많은 비율을 차지하고 있는 주요한 알러젠이다(Mine and Yang, 2008). $45 \mathrm{kDa}$ 의 분자량을 가지고 있는 인당단백질(phosphoglycoprotein)인 OVA는 단백질의 구조나 기능 연구를 위한 표준 물질로서 사용될 뿐만 아니라, 알러지 연구를 위한 실험동물 모델에 광범위하게 사용되고 있다(Mine and Yang, 2008). 현재까지 널리 알려진 계란 알러지 치료 방법은 계란을 먹지 않고 피하는 것이다. 하지만 오늘날 음식문화의 발달로 많은 음식에 계란을 이용하면서 계란 을 피하는 것은 더욱 어려워지고 있다. 특히 계란을 활용 하여 MMR (measles, mumps, rubella) 백신을 포함한 여러 바이러스 백신들을 제조하고 있기 때문에, 현대사회에서 는 계란 알러젠이 중요한 이슈로 떠오르고 있다(Mine and Yang, 2008).

염증(inflammation)은 박테리아나 바이러스와 같은 여러 병원균의 자극에 대한 보호 반응으로 작용한다. 하지만 계 속된 병원균의 자극으로 인한 만성염증은 오히려 여러 질병을 유도하는 것으로 알려져 있다(Ferrero-Miliani et al., 2007). 염증 유발 원인은 여러 분자학적인 기전이 알려져 있지만, 그 중에서 inducible nitric oxide synthase (iNOS)에 의한 nitric oxide (NO) 생성이 염증 유발에 중요한 기능을 하는 것으로 알려져 있다(Moncada, 1999; Turini and DuBois,

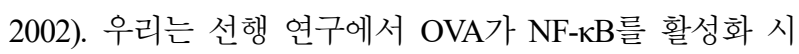
키며, 활성화된 NF- $\mathrm{KB}$ 에 의해서 유도되는 단백질인 iNOS 의 발현을 유도하는 것을 알아내었다(Lee et al., 2011).

전통적으로 우리 식생활에서 즐겨먹던 식물들 중에는 항암 - 항염증 효과를 가지고 있다고 알려져 있는 많은 기 능성 소재들이 포함되어 있다(Youn, 2012). 그 중에서 우 리가 들에서 흔히 볼 수 있는 쑥부쟁이가 있다. 쑥부쟁이 잎은 소화를 잘되게 하고 혈압을 내리며, 기침과 천식에 좋고, 해열제와 이뇨제로 쓰인다고 알려져 있다(Kim et al., 2014). 그래서 우리는 이번 연구를 통해서 쑥부쟁이 에탄올 추출물이 OVA에 의해서 유도된 NF- $\mathrm{KB}$ 활성화와 활성화된 NF- $\mathrm{NB}$ 에 의해서 유도되는 유전자인 $\mathrm{iNOS}$ 의 발 현을 어떻게 조절하는지 알아보고자 한다. 이러한 연구는
천연 추출물을 활용한 알러지 예방 및 치료제 개발에 초 석이 될 것으로 기대한다.

\section{재료 및 방법}

\section{재료}

실험에 사용한 ovalbumin은 Sigma-Aldrich (St. Louis, MO, USA), LPS는 List Biological Lab (San Jose, CA, USA)로부터 구입하였다. iNOS 항체는 BD Biosciences (San Jose, CA, USA)와 $\beta$-actin 항체는 Santa Cruz Biotechnology (Santa $\mathrm{Cruz}, \mathrm{CA}, \mathrm{USA}$ )로부터 구입하였다. 그 밖의 다른 시약들 은 Sigma-Aldrich 회사로부터 구입하였다.

\section{쑥부쟁이 추출물 준비}

쑥부쟁이 잎은 전라남도 농업기술센터에서 구입하였다. 쑥부쟁이 건조된 잎은 4 시간 동안 $87^{\circ} \mathrm{C}$ 에서 $50 \%$ 에탄올 을 가지고 추출하였다. 이 과정은 세 번 반복하였다. 쑥부 쟁이 $50 \%$ 에탄올 추출물은 실험을 위하여 농축되고 건조 되었다. 건조된 추출물은 실험을 위하여 dimethyl sulfoxide (DMSO)에 녹여서 사용하였다.

\section{세포 배양}

RAW 264.7 cells (a murine monocytic cell line, ATCC TIB-71)은 $10 \%$ (v/v) FBS, 100 units/mL penicillin, $100 \mu \mathrm{g} / \mathrm{mL}$ streptomycin을 포함하고 있는 Dulbecco's modified Eagle's medium (DMEM)에서 배양하였으며, 세포들은 $5 \% \mathrm{CO}_{2} / \mathrm{air}$ 를 포함하고 있는 $37^{\circ} \mathrm{C}$ 배양기 안에서 배양하였다.

\section{세포 생존율 시험(MTS assay)}

세포 생존율 시험은 선행 연구에 사용하였던 방식을 따라 하였다(Ahn et al., 2015). 세포 생존율은 잘 알려진 3-(4,5-dimethylthiazol-2-yl)-5(3-carboxymethoxyphenyl)-2-)4sulfophenyl)-2H-tetrazolium (MTS)을 사용한 색깔변화에 의 해서 평가하였다. 세포 생존율 시험은 Cell Titer 96 Aqueous One Solution Reagent (Promega)을 가지고 제조사의 방법 에 따라서 측정하였다.

\section{트랜스펙션(transfection)과 발광효소 유전자 분석(lucif- erase reporter gene assay)}

발광효소 유전자 분석은 선행 연구에서 사용한 방법에 의하여 분석하였다(Youn et al., 2006c). 발광효소 plasmid 와 HSP70- $\beta$-galactosidase plasmid는 Superfect transfection 
A

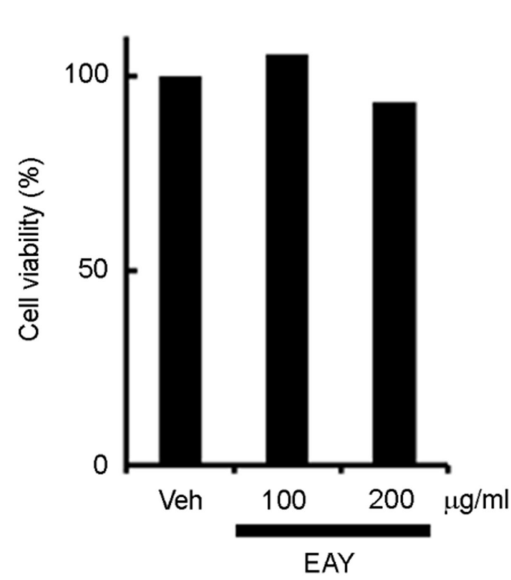

B

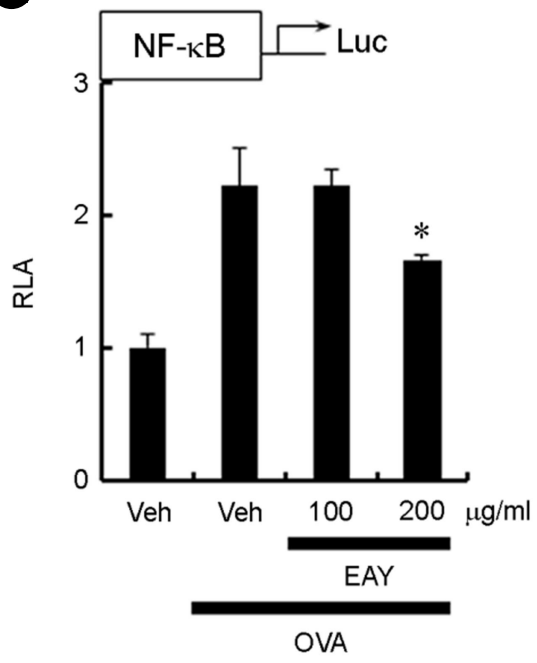

C

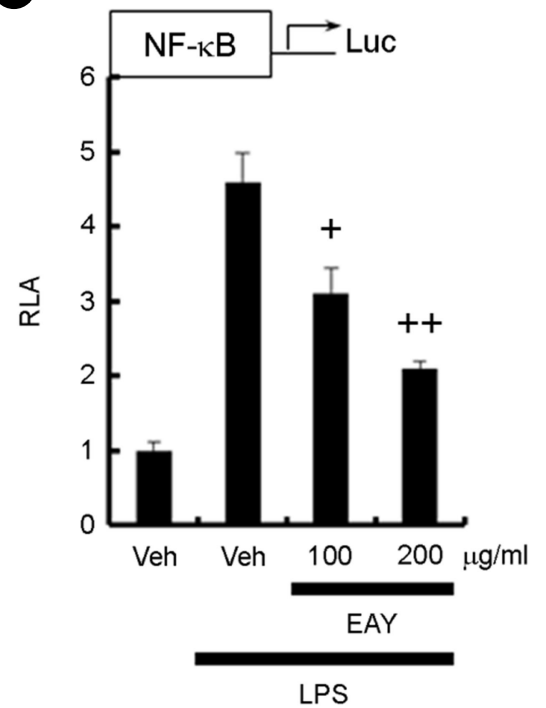

Fig. 1. Ethanol extracts of Aster yomena (EAY) inhibits NF-кB activation induced by OVA or LPS. A) RAW264.7 cells were treated with EAY $(100,200 \mathrm{mg} / \mathrm{ml})$ for $4 \mathrm{~h}$. Twenty microliters of the CellTiter $96 \mathrm{AQ}_{\text {ueous }}$ One Solution Reagent was added directly to culture wells. The plate was incubated at $37^{\circ} \mathrm{C}$ for $4 \mathrm{~h}$ in a humidified, $5 \% \mathrm{CO}_{2}$ atmosphere. The absorbance was recorded at $490 \mathrm{~nm}$ with a 96 -well plate reader. B, C) RAW264.7 cells were transfected with NF-kB luciferase reporter plasmid and pretreated with $100 \mathrm{or} 200 \mathrm{mg} / \mathrm{ml}$ EAY for $1 \mathrm{~h}$ and then treated with OVA $(100 \mu \mathrm{g} / \mathrm{ml})(\mathrm{B})$ or LPS $(10 \mathrm{ng} / \mathrm{ml})(\mathrm{C})$ for an additional $8 \mathrm{~h}$. Cell lysates were prepared and luciferase enzyme activities were determined. Values are expressed as the mean \pm SEM $(n=3)$. *, Significantly different from OVA alone, $P<0.05(*)$.,+ Significantly different from LPS alone, $P<0.05(+), P<0.01(++)$. RLA, relative luciferase activity; Veh, vehicle; EAY, ethanol extracts of Aster yomena.

시약(Qiagen, Valencia, CA, USA)을 사용하여 세포 안으로 transfection 시켰다. 발광효소의 활성화는 luciferase assay system (Promega, Madison, WI, USA)을 사용하여 측정하였 다. 발광효소의 활성화는 $\beta$-galactosidase의 활성화를 측정 하여 표준화시켰다.

\section{면역압(immunoblotting)방법}

Western blotting은 선행 연구의 방법에 의하여 분석하였 다(Youn et al., 2006a; Youn et al., 2006b). 단백질 추출물들 은 SDS-PAGE (sodium dodecyl sulfate-polyacrylamide gel electrophoresis)에서 분리되어 polyvinylidene difluoride membrane으로 전기영동에 의해서 이전되었으며, membrane은 $0.1 \%$ Tween 20 그리고 5\% 탈지 건조된 우유를 포함하고 있는 phosphate-buffered saline을 가지고 blocking 하였다. Membrane은 1차 항체를 가지고 blotting하고, horseradish peroxidase와 복합된 2차 항체에 노출시킨 다음, $\mathrm{ECL}$ western blot detection 시약(Amersham Biosciences, Arlington Heights, IL, USA)을 사용하여 단백질을 규명하였다.
Nitrite assay

선행 연구의 방법에 의하여 RAW264.7 세포로부터 nitrite 추출물이 준비되었다(Lim et al., 2008). Supernatant $100 \mu \mathrm{l}$ 씩 96 well plate에 넣고, 분주기를 사용하여 Griess reagent (1\% sulfanilamide and $0.1 \%$ naphthylethylene diamine in a $2.5 \%$ phosphoric acid solution) $150 \mu \mathrm{l}$ 를 첨가하였다. 공 기를 제거한 후 플레이트 리더기를 사용하여 $570 \mathrm{~nm}$ 에서 흡광도를 측정하였다. 표준용액으로 sodium nitrite 용액이 사용되었다.

\section{데이타 분석}

각각의 데이타 값은 세 개가 한벌의 실험으로 얻어졌 으며, mean \pm standard error mean (SEM)으로 표현되었다.

\section{결 과}

쑥부쟁이 에탄올 추출물은 OVA 또는 LPS에 의해 유도 된 $\mathrm{NF}-\kappa \mathrm{B}$ 활성화 억제

쑥부쟁이 에탄올 추출물의 세포 독성을 측정하기 위해 
서 MTS assay를 사용하여 세포 생존율을 확인하였다. 쑥 부쟁이 에탄올 추출물은 $200 \mu \mathrm{g} / \mathrm{ml}$ 의 농도에서 $93 \%$ 이상 의 세포 생존율을 보여주었다(Fig. 1A). 그래서 쑥부쟁이 에탄올 추출물의 세포 독성은 배제될 수 있어서 모든 실 험은 $200 \mu \mathrm{g} / \mathrm{ml}$ 농도까지 사용되었다.

$\mathrm{NF}-\kappa \mathrm{B}$ 는 발달(development), 염증(inflammation), 면역 (immunity)을 위해서 중요한 역할을 하는 것으로 알려져 있는 세포 안에 있는 전사 요소다(Pahl, 1999). 활성화된 $\mathrm{NF}-\kappa \mathrm{B}$ 는 cytokine과 chemokine을 포함한 면역·염증에 관 여하는 여러 종류 타깃 유전자의 발현을 조절하여 암이나 여러 질병을 유발하는 것으로 알려져 있다. 그래서 NF$\kappa \mathrm{B}$ 활성화를 조절할 수만 있다면 염증 유도 물질들을 줄여서 여러 질병으로부터 숙주를 보호할 수 있다(Pahl, 1999). 먼저 우리는 쑥부쟁이 에탄올 추출물이 계란 알러 젠인 OVA 또는 LPS에 의해서 유도된 NF- $\kappa \mathrm{B}$ 활성화에 어떤 영향을 미치는지 발광효소 유전자 분석법(luciferase assay)을 활용해서 알아보았다. 쑥부쟁이 에탄올 추출물은 OVA 또는 LPS에 의해서 유도된 NF-kB 활성을 억제하였 다(Figs. 1B, C).

\section{쑥부쟁이 에탄올 추출물은 OVA 또는 LSP에 의해 유도 된 iNOS 발현 억제}

다음 실험으로 쑥부쟁이 에탄올 추출물이 NF-kB 활성 화에 의해서 유도되는 유전자인 iNOS 발현에 어떠한 영 향을 미치는지 알아보았다. 먼저 발광효소 유전자 분석법 이 사용되었다. iNOS 발광효소 유전자 분석법에 의하면 쑥부쟁이 에탄올 추출물은 OVA 또는 LPS에 의해서 유도 된 iNOS 발현을 억제시켰다(Figs. 2A, 2B). 다음으로 쑥부 쟁이 에탄올 추출물은 OVA 또는 LPS에 의해서 유도된 iNOS 단백질 발현을 억제시키는 것을 Western blotting 방 법을 통하여 확인하였다(Figs. 3A, B). 또한 쑥부쟁이 에탄 올 추출물은 OVA 또는 LPS에 의해서 유도된 iNOS에 의 한 생성물인 nitrite의 생성을 억제하였다(Figs. 4A, B).

\section{고 찰}

알러지는 숙주 면역 시스템의 과민반응이라 할 수 있 으며, 이러한 면역 반응은 붉어짐(redness), 발열(heat), 부 종(swelling), 통증(pain)을 포함하는 여러 증상에 따른 염 증반응(inflammation)이라 할 수 있다. 염증 반응(inflammation)은 iNOS에 의한 nitric oxide (NO) 생산이 중요한 역 할을 하는 것으로 알려져 있다(Moncada, 1999; Turini and
A

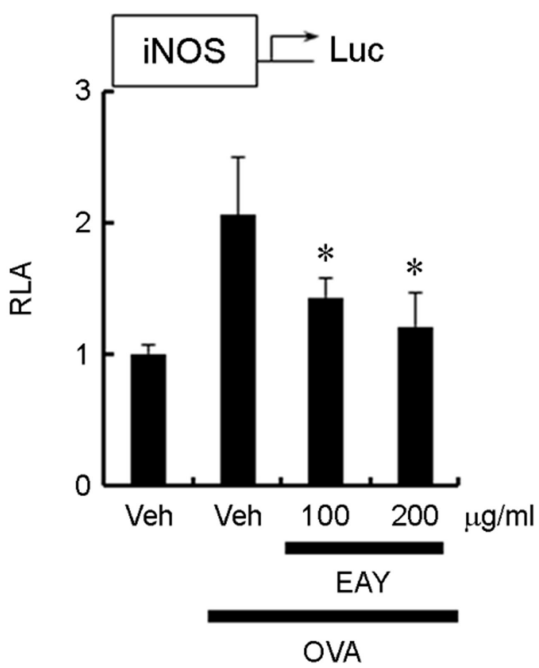

B

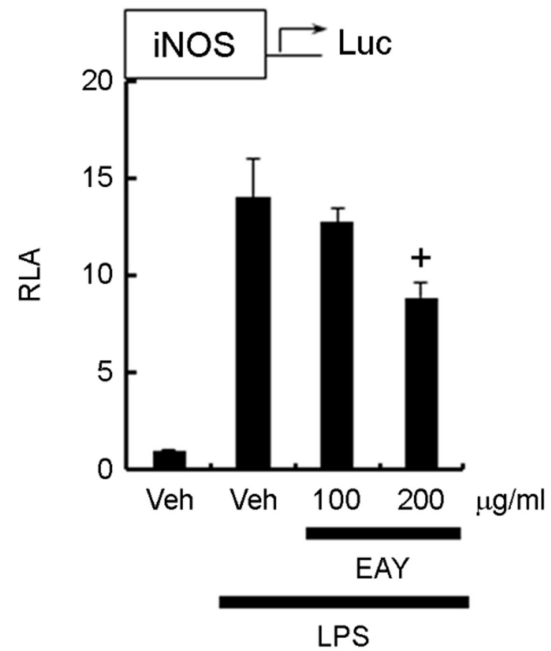

Fig. 2. Ethanol extracts of Aster yomena (EAY) suppress iNOS expression induced by OVA or LPS. A, B) RAW264.7 cells were transfected with iNOS luciferase reporter plasmid and pretreated with 100 or $200 \mathrm{mg} / \mathrm{ml}$ EAY for $1 \mathrm{~h}$ and then treated with OVA $(100 \mu \mathrm{g} / \mathrm{ml})(\mathrm{A})$ or LPS $(10 \mathrm{ng} / \mathrm{ml})(B)$ for an additional $8 \mathrm{~h}$. Cell lysates were prepared and luciferase enzyme activities were determined. Values represent the mean $\pm \operatorname{SEM}(\mathrm{n}=3)$. *, Significantly different from OVA alone, $P<0.05\left(^{*}\right)$. + , Significantly different from LPS alone, $P<0.05(+)$. RLA, relative luciferase activity; Veh, vehicle; EAY, ethanol extracts of Aster yomena.

DuBois, 2002).

Nitric oxide (NO)는 1987년까지 전기화학반응의 오염물 질이나 부산물로 여겨져 왔지만, 오늘날에는 포유동물 세 포가 아미노산 L-arginine으로부터 $\mathrm{NO}$ 를 만들고, 이 $\mathrm{NO}$ 는 세포에서 다른 세포 사이의 신호전달을 위해 사용하는 
A

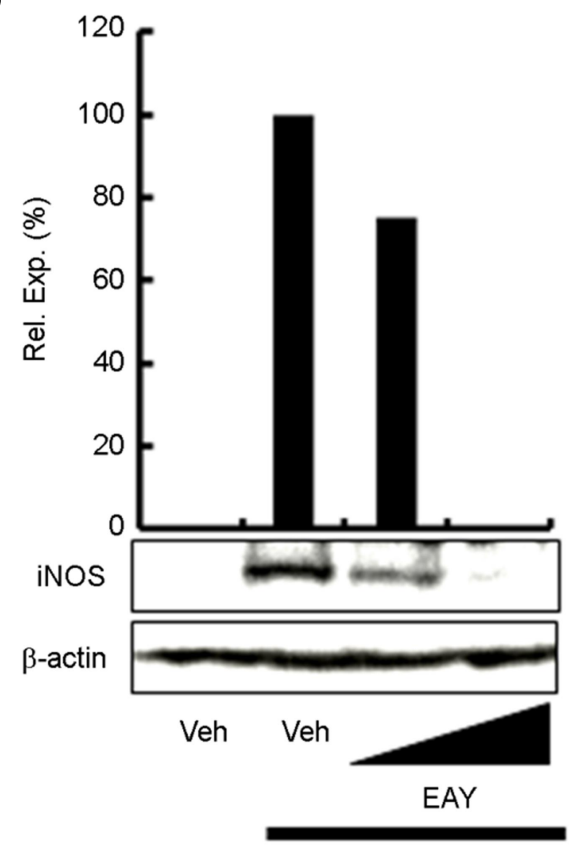

OVA

B

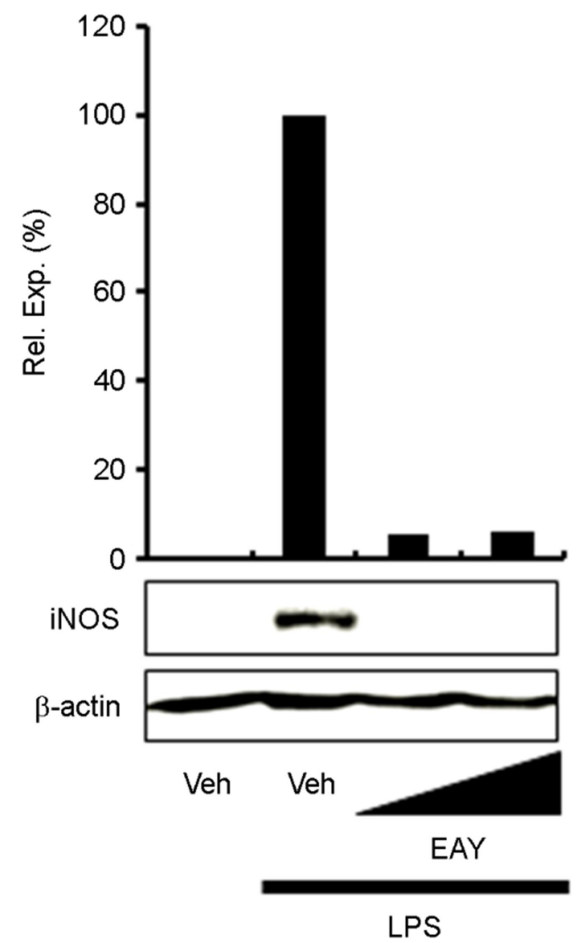

Fig. 3. Ethanol extracts of Aster yomena (EAY) suppress iNOS protein induced by OVA or LPS. A, B) RAW264.7 cells were pretreated with 100 or $200 \mathrm{mg} / \mathrm{ml}$ EAY for $1 \mathrm{~h}$ and then further stimulated with OVA $(100 \mu \mathrm{g} / \mathrm{ml})$ (A) or LPS $(10 \mathrm{ng} / \mathrm{ml})(B)$ for 8 $\mathrm{h}$. Cell lysates were analyzed for iNOS and $\beta$-actin protein by immunoblots. Veh, vehicle; EAY, ethanol extracts of Aster yomena.
A

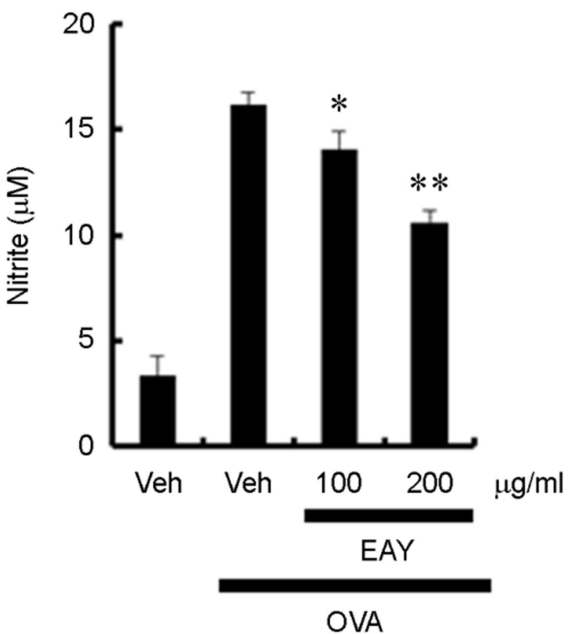

B

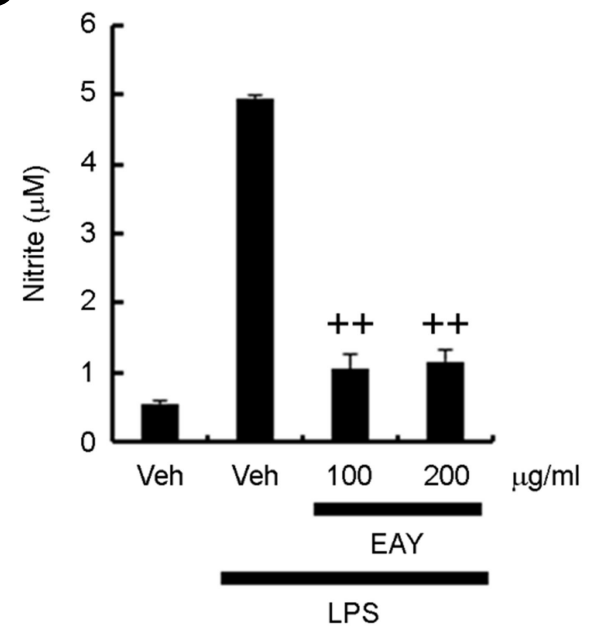

Fig. 4. Ethanol extracts of Aster yomena (EAY) suppress nitrite production induced by OVA or LPS. A, B) RAW 264.7 cells were pretreated with 100 or $200 \mathrm{mg} / \mathrm{ml} \mathrm{EAY} \mathrm{for} 1 \mathrm{~h}$ and then treated with OVA $(100 \mu \mathrm{g} / \mathrm{ml})$ (A) or LPS (10 $\mathrm{ng} / \mathrm{ml})$ (B) for an additional $20 \mathrm{~h}$. The amounts of nitrite in supernatant were measured using Griess reagent. Values represent the mean $\pm \operatorname{SEM}(\mathrm{n}=3) . *$ Significantly different from OVA alone, $P<0.05\left(^{*}\right), P<0.01(* *)$. + , Significantly different from LPS alone, $P<0.01(++)$. RLA, relative luciferase activity; Veh, vehicle; EAY, ethanol extracts of Aster yomena.

것으로 알려져 있다(Hanafy et al., 2001). NO는 aconitase, $\mathrm{NADH}$ dehydrogenase, succinate dehydrogenase를 포함한 Fe-S clusters를 가지고 있는 효소들과, non-haem metalloenzymes, ribonucleotide reductase, DNA 등에 영향을 미치 는 것으로 알려져 있다(Burney et al., 1999). 또한, NO는 단백질 안에 있는 cysteine을 니트로실화(nitrosylation) 함으 로써 단백질의 기능을 변형시킨다(Stamler et al., 2001). NO 
의 생성은 endothelial NOS (eNOS), neuronal NOS (nNOS), inducible NOS (iNOS) 등 3개의 NOSs에 의해서 유도된다 (Vallance, 2003). iNOS는 염증을 유발하는 요소에 의해서 유도되는 효소인데 반해서, eNOS, nNOS는 항상 발현되어 있는 효소이다(Vallance, 2003). 동물의 병리생리학과 가장 분명하게 연결된 것은 iNOS의 과발현이라 할 수 있으며, iNOS는 최초로 쥐 대식세포(murine macrophages) 안에서 발견되었다(Green et al., 1990). 다양한 pro-inflammatory cytokines (interleukin-1, interferon- $\gamma$, tumor necrosis factor- $\alpha$ ) 의 자극에 의해서 $\mathrm{iNOS}$ 는 활성화되며 $\mathrm{iNOS}$ 단백질이 발 현되는 것으로 알려져 있다(Palmer et al., 1993). 특히, iNOS 에 의해서 생성된 nitric oxide는 peroxynitrite를 형성하기 위하여 $\mathrm{O}_{2}$ 와 결합했을 때, 여러 효소와 신호전달 체계에 영향을 미치는 것으로 알려져 있다(Vallance, 2003).

$\mathrm{NF}-\kappa \mathrm{B}$ 는 염증을 유발하는 다양한 병원체의 자극에 의 하여 활성화 되므로, NF- $\kappa \mathrm{B}$ 활성 억제는 항염증 치료제 개발에 중요한 전략으로 여겨진다(Akira and Takeda, 2004). 그러므로 이번 연구에서 우리는 염증을 유발하는데 중요 한 요소인 NF- $\mathrm{BB}$ 활성화와 iNOS 발현을 쑥부쟁이 에탄 올 추출물이 조절할 수 있는지 연구하였다. 쑥부쟁이 에 탄올 추출물은 OVA과 LPS에 의해서 유도된 NF-kB 활성 화와 iNOS 발현을 억제하였다. 이러한 결과는 쑥부쟁이 에탄올 추출물이 염증 조절물질로써 중요한 역할을 할 수 있다는 것을 제안한다.

TLR4는 MyD88과 TRIF 두 개의 신호전달 시스템을 활 성화 시킨다(Takeda and Akira, 2005). LPS가 TLR4 신호전 달 시스템을 활성화하면, 전사 요소 NF- $\mathrm{KB}$ 와 IRFs의 활성 화를 유도하여 cytokine, iNOS와 같은 염증을 유발하는 유 전체들을 유도하여 암이나 질병을 유발하게 된다(Takeda and Akira, 2005). LPS에 의해 유도된 대다수의 유전자들은 TRIF-dependent 신호전달 시스템을 통하여 조절되는 것으 로 알려져 있다(Bjorkbacka et al., 2004). 또한 LPS에 의해 유도된 iNOS 발현의 대부분은 TRIF-dependent 신호전달 시스템에 의해 조절된다고 보고되었다(Gao et al., 1998). 미래에는 쑥부쟁이 추출물이 TRIF-dependent 신호전달 시 스템을 어떻게 조절하여 NF- $\mathrm{KB}$ 활성화와 $\mathrm{iNOS}$ 발현을 억제하는지 그 작용기전을 규명하고자 한다.

이번 연구에서 쑥부쟁이 에탄올 추출물이 계란 알러젠 중의 하나인 OVA 또는 TLR4 agonist인 LPS에 의해서 유 도된 $\mathrm{iNOS}$ 발현에 어떤 영향을 미치는지 알아보았다. 우 리는 쑥부쟁이 에탄올 추출물이 OVA 또는 LPS에 의해 유도된 NF- $\mathrm{KB}$ 활성화와 $\mathrm{iNOS}$ 발현을 억제하는 것을 밝
혀내었다. 이러한 결과는 쑥부쟁이 추출물이 OVA 또는 LPS에 의해서 유도된 염증 또는 알러지와 같은 만성적인 질병들을 조절할 수 있다는 것을 보여주는 중요한 결과 라 할 수 있겠다.

\section{ACKNOWLEDGEMENTS}

본 연구는 순천향대학교 학술연구비의 일부 지원과 농촌진흥청의 농축산물부가가치향상-농축산물기능성평 가(연구제목: 국내 자생 쑥부쟁이의 항알레르기, 항염증 메카니즘 구명 및 기능성 원료 등록 연구, Project No: PJ0108262015)"로 수행하였으므로 이에 감사를 드립니다.

\section{CONFLICT OF INTEREST}

The authors have no conflicts of interest to disclose.

\section{REFERENCES}

Ahn SI, Lim SJ, Gu GJ, Hong CY, Kim JS, Jeong HJ, Koh KO, Mang JY, Kim DY, Youn HS. Suppressive effects of 1-[4fluoro-2-(2-nitrovinyl)phenyl]pyrrolidine on the Toll-like receptor signaling pathways. International Immunopharmacology. 2015. 24: 36-41.

Akira S, Takeda K. Toll-like receptor signaling. Nature Review Immunology. 2004. 4: 499-511.

Bjorkbacka H, Fitzgerald KA, Huet F, Li X, Gregory JA, Lee MA, Ordija CM, Dowley NE, Golenbock DT, Freeman MW. The induction of macrophage gene expression by LPS predominantly utilizes Myd88-independent signaling cascades. Physiology Genomics. 2004. 19: 319-330.

Burney S, Caulfield JL, Niles JC, Wishnok JS, Tannenbaum SR. The chemistry of DNA damage from nitric oxide and peroxynitrite. Mutation Research. 1999. 424: 37-49.

Eggesbo M, Botten G, Halvorsen R, Magnus P. The prevalence of allergy to egg: a population-based study in young children. Allergy. 2001. 56: 403-411.

Ferrero-Miliani L, Nielsen OH, Andersen PS, Girardin SE. Chronic inflammation: importance of NOD2 and NALP3 in interleukin1beta generation. Clinical \& Experimental Immunology. 2007. 147: 227-235.

Gao JJ, Filla MB, Fultz MJ, Vogel SN, Russell SW, Murphy WJ. Autocrine/paracrine IFN-alphabeta mediates the lipopolysaccharide-induced activation of transcription factor Statlalpha in mouse macrophages: pivotal role of Statlalpha in induction 
of the inducible nitric oxide synthase gene. Journal of Immunology. 1998. 161: 4803-4810.

Green SJ, Meltzer MS, Hibbs JB Jr, Nacy CA. Activated macrophages destroy intracellular Leishmania major amastigotes by an L-arginine-dependent killing mechanism. Journal of Immunology. 1990. 144: 278-283.

Hanafy KA, Krumenacker JS, Murad F. NO, nitrotyrosine, and cyclic GMP in signal transduction. Medical Science Monitor. 2001. 7: 801-819.

Kawai T, Akira S. Signaling to NF-kappaB by Toll-like receptors. Trends in Molecular Medicine. 2007. 13: 460-469.

Kim AR, Jin Q, Jin HG, Ko HJ, Woo ER. Phenolic compounds with IL-6 inhibitory activity from Aster yomena. Archives Pharmacal Research. 2014. 37: 845-851.

Lee AN, Park SJ, Jeong AR, Lee JR, Park HJ, Kim SJ, Min IS, Youn HS. Ovalbumin induces cycloxygenase- 2 and inducible nitric oxide synthase expression. Korean Journal of Food Science Technology. 2011. 43: 110-113.

Lim HJ, Lee HS, Ryu JH. Suppression of inducible nitric oxide synthase and cyclooxygenase-2 expression by tussilagone from Farfarae flos in BV-2 microglial cells. Archives Pharmacal Research. 2008. 31: 645-652.

Mine Y, Yang M. Recent advances in the understanding of egg allergens: basic, industrial, and clinical perspectives. Journal of Agricultural and Food Chemistry. 2008. 56: 4874-4900.

Moncada S. Nitric oxide: discovery and impact on clinical medicine. Journal of the Royal Society Medicine. 1999. 92: 164-169.

Pahl HL. Activators and target genes of Rel/NF-kappaB transcription factors. Oncogene. 1999. 18: 6853-6866.

Palmer RM, Hickery MS, Charles IG, Moncada S, Bayliss MT. Induction of nitric oxide synthase in human chondrocytes. Biochemical and Biophysical Research Communications. 1993. 193: 398-405.

Stamler JS, Lamas S, Fang FC. Nitrosylation. the prototypic redox- based signaling mechanism. Cell. 2001. 106: 675-683.

Takeda K, Akira S. Toll-like receptors in innate immunity. International Immunology. 2005. 17: 1-14.

Turini ME, DuBois RN. Cyclooxygenase-2: a therapeutic target. Annual Review of Medicine. 2002. 53: 35-57.

Vallance P. Nitric oxide: therapeutic opportunities. Fundamental \& Clinical Pharmacology. 2003. 17: 1-10.

Wang J, Sampson HA. Food allergy: recent advances in pathophysiology and treatment. Allergy Asthma \& Immunology Research. 2009. 1: 19-29.

Youn HS. The anti-inflammatory effects of phytochemicals by the modulation of innate immunity. Journal of Experimental \& Biomedical Sciences. 2012. 18: 181-192.

Youn HS, Lee JY, Saitoh SI, Miyake K, Hwang DH. Auranofin, as an anti-rheumatic gold compound, suppresses LPS-induced homodimerization of TLR4. Biochemical and Biophysical Research Communications. 2006. 350: 866-871.

Youn HS, Lee JY, Saitoh SI, Miyake K, Kang KW, Choi YJ, Hwang DH. Suppression of MyD88- and TRIF-dependent signaling pathways of Toll-like receptor by (-)-epigallocatechin-3-gallate, a polyphenol component of green tea. Biochemical Pharmacology. 2006. 72: 850-859.

Youn HS, Saitoh SI, Miyake K, Hwang DH. Inhibition of homodimerization of Toll-like receptor 4 by curcumin. Biochemical Pharmacolgy. 2006. 72: 62-69.

http://dx.doi.org/10.15616/BSL.2017.23.2.104

Cite this article as: Kim AY, Shin HM, Kim JS, Shim HJ, Nam KW, Hwang KA, Youn HS. Anti-inflammatory Effects of Aster yomena Extracts by the Suppression of Inducible Nitric Oxide Synthase Expression. Biomedical Science Letters. 2017. 23: 104-110. 